\title{
Optimasi Volume Larutan Prekursor Natrium Silikat Hasil Pengolahan Abu Sekam Padi Terhadap Kelenturan Plastik Komposit SilikaTerimobilisasi EDTA-Ag dan Kitosan
}

\author{
Hermania Em Wogo ${ }^{\mathrm{a}}$, Martha C.W. Ndoen ${ }^{\mathrm{b}}$ \\ Fakultas Sains dan Teknik, Universitas Nusa Cendana, Kupang, NTT, Indonesia,email: mar29ndoen@gmail.com
}

Artikel Ini Telah Diseminarkan Pada Seminar Nasional Saintek Unimor 2019

\section{Article Info}

\section{Article history:}

Received 23 Oktober 2019

Received in revised form 23 Mei 2020

Accepted 1 Juni 2020

DOI:
https://doi.org/10.32938/slk.v3i1.1025

Keywords:

Silika

Kitosan

Imobilisasi

Plastik

Elongasi

\section{Abstrak}

Sekam padi merupakan salah satu sumber penghasil silika terbesar dan dapat dimanfaatkan menjadi natrium silikat yang kemudian disintesis menjadi silika gel. Penelitian ini dilakukan untuk mengetahui volume optimum larutan prekursor natrium silikat hasil pengolahan abu sekam padi terhadap kelenturan plastik komposit silika terimobilisasi EDTA-Ag dan kitosan. Silika yang digunakan berasal dari hasil destruksi abu sekam padi menggunakan $\mathrm{NaOH}$. Kandungan silika dalam abu sekam padi yang digunakan dalam penelitian ini adalah 93,608\%. Volume larutan natrium silikat yang digunakan adalah $10 \mathrm{~mL}, 30 \mathrm{~mL}$ dan $50 \mathrm{~mL}$, sedangkan variasi kitosan yang digunakan adalah 0,3 gram dan 0,7 gram. Hasil uji luas permukaan dengan metode titrasi menunjukkan bahwa keasaman permukaan silika termobilisasi EDTA-Ag terting gi yaitu pada volume natrium silikat $30 \mathrm{~mL}$ sebesar $3,4 \mathrm{mmol} / \mathrm{g}$, sedangkan luas permukaan optimum yang diperoleh dengan metode metilen biru yaitu $17,6113 \mathrm{~m}^{2} / \mathrm{g}$ untuk volume natrium silikat $30 \mathrm{~mL}$ pada waktu kontak 80 menit. Berdasarkan hasil karakterisasi menggunakan FTIR, silika terimobilisasi EDTA-Ag yang disintesis mengandung gugus-OH dari silika gel (3444,63 $\left.\mathrm{cm}^{-1}\right)$, gugus Si-OH dari silika gel $\left(1083,92 \mathrm{~cm}^{-1}\right)$, gugus $-\mathrm{CH}_{2}-\left(1384,79 \mathrm{~cm}^{-1}\right)$ dan gugus $-\mathrm{NHCOCH}_{3}$ dari EDTA $\left(1639,38 \mathrm{~cm}^{-1}\right)$. Pada uji mekanis untuk plastik dari komposit silika terimobilisasi EDTA-Ag dan kitosan, diperoleh persen elongasi tertinggi adalah pada variasi kitosan 0,3 gram sebesar 27,5\%.@2020 dipublikasikan oleh JSLK.

\section{Pendahuluan}

Peran plastik dalam kehidupan masyarakat sehari-hari sangat besar. Hal ini mengakibatkan penggunaan plastik di masyarakat semakin meningkat, seperti digunakan sebagai pembungkus makanan, tempat makan dan minum, dan lain sebagainya. Plastik digunakan karena memiliki keuntungan, yaitu ringan dan ekonomis. Namun plastik memiliki bahaya dan sulit terdegradasi dilingkungan karena pada dasarnya semua jenis plastik terbuat dari minyak bumi dengan campuran berbagai bahan kimia yang beracun. Oleh karena itu, dikembangkan plastik antibakteri dari polimer alami seperti silika gel.

Salah satu sumber silika adalah sekam padi yang merupakan hasil penggilingan padi (sebesar $20 \%$ dari produksi padi), sedangkan jumlah abu sekam adalah sebesar 18\% dari jumlah sekam (Folleto dkk., 2006). Kandungan silika yang terdapat dalam abu sekam padi adalah sebesar 89-97\% (Kalapathy dkk., 2002; Nuryono, 2004; Da Silva, 2009; Tambaru dkk., 2010). Kandungan silika yang terdapat dalam abu sekam padi ini, dapat dimanfaatkan menjadi natrium silikat $\left(\mathrm{Na}_{2} \mathrm{SiO}_{3}\right)$ yang kemudian dapat disintesis menjadi silika gel.

Silika gel merupakan bentuk silika yang diperoleh melalui reaks penggumpalan sol natrium silikat $\left(\mathrm{Na}_{2} \mathrm{SiO}_{3}\right)$. Silika gel dapat digunakan sebagai adsorben karena mudah dimodifikasi dan diproduksi (Fahmiati dkk., 2004). Kemampuan adsorpsi silika gel bergantung pada jumlah gugus $-\mathrm{OH}$ per satuan luas adsorben (Oscik, 1982). Silika juga memiliki potensi untuk digunakan sebagai agen anti bakteri.

Menurut Hyung dkk (2003), agen anti bakteri alami lain seperti kitosan dapat digunakan sebagai bahan baku dalam pembuatan plastik. Kitosan memiliki gugus fungsional amina $\left(-\mathrm{NH}_{2}\right)$ yang bermuatan positif, sehingga mampu menarik molekul asam amino bermuatan negatif pembentuk protein dalam mikroba. Kitosan bersifat tahan air, tidak beracun dan terbukti dapat menghambat pertumbuhan jamur, bakteri dan kapang sehingga berfungsi sebagai pengawet (Prasetyo, 2004).

Wogo dkk (2017) berhasil mensintesis komposit silika gel terimobilisasi EDTA-Ag dan kitosan dalam pembuatan plastik antibakteri yang mampu membunuh bakteri Escherichia coli dan Staphylococcus aureus sebesar 99,99\%, namun plastik tersebut memiliki struktur yang cukup kaku, Oleh karena itu, pada penelitian ini dilakukan variasi perlakuan untuk mengetahui penyebab struktur plastik yang kaku tersebut dan optimasi volume larutan prekursor natrium silikat dalam pembuatan plastik anti bakteri.

\section{Metode}

\subsection{Alat dan Bahan}

Alat yang digunakan dalam penelitian ini berupa peralatan gelas, ayakan 60 mesh, magnetic stirrer, cawan petri, Spektrofotometer UV-Vis dan Spektrofotometer Fourier Transform Infra Red (FTIR).

Bahan-bahan yang digunakan dalam penelitian ini berupa sekam padi, $\mathrm{HCl}$, $\mathrm{NaOH}, \mathrm{CH}_{3} \mathrm{COOH}, \mathrm{AgNO}_{3}$, EDTA, metilen biru dan kitosan

\subsection{Prosedur Kerja}

\subsubsection{Preparasi Abu Sekam Padi}

Sekam padi dibersihkan dari kotoran, dicuci, dibilas dan dikeringkan pada suhu $110^{\circ} \mathrm{C}$. Kemudian sekam padi disangrai hingga berwarna hitam dan diabukan selama \pm 4 jam pada suhu $700{ }^{\circ} \mathrm{C}$. Sampel digerus dan diayak menggunakan ayakan 60 mesh. Diambil $20 \mathrm{~g}$ abu sekam padi hasil ayakan dan dicuci dengan $120 \mathrm{~mL} \mathrm{HCl} 6 \mathrm{M}$ dan diaduk selama 1 jam. Kemudian dibilas kembali dengan akuades sampai $\mathrm{pH}$ netral dan dikeringkan pada suhu $110{ }^{\circ} \mathrm{C}$.

2.2.2 Pembuatan larutan Natrium Silikat
20 gram abu sekam padi dilarutkan dengan $\mathrm{NaOH} 2 \mathrm{M}$ sebanyak 330 $\mathrm{mL}$, dididihkan sambil diaduk hingga mengental dan didestruksi selama 30 menit pada suhu $500{ }^{\circ} \mathrm{C}$, ditambahkan akuades $200 \mathrm{~mL}$ dan didiamkan semalam lalu disaring.

\subsubsection{Pembuatan Silika Gel Terimobilisasi EDTA-Ag}

Larutan natrium silikat dengan volume yang berbeda yakni 10, 30 dan $50 \mathrm{~mL}$ dimasukkan ke dalam wadah plastik, masing-masing ditambahkan 5 mL larutan EDTA 0,005 $\mathrm{M}$ dan $5 \mathrm{~mL}$ larutan $\mathrm{AgNO}_{3}$ 0,005, dihomogenkan, ditambahkan sedikit demi sedikit larutan $\mathrm{HCl} 3 \mathrm{M}$ sambil diaduk hingga terbentuk gel, didiamkan semalam, disaring dan dicuci dengan akuades sampai netral $(\mathrm{pH}=7)$, dikeringkan pada suhu $110{ }^{\circ} \mathrm{C}$, digerus dan diayak dengan menggunakan ayakan 60 mesh. Kemudian dikarakterisasi menggunakan Spektrofotometer Fourier Transform Infra Red (FTIR).

\subsubsection{Penentuan Keasaman}

Sebanyak 0,5 gram silika gel terimobilisasi EDTA-Ag ditambahkan $25 \mathrm{~mL} \mathrm{NaOH} 1 \mathrm{M}$ yang telah dibakukan, diaduk selama 2 jam pada temperatur kamar. Perlakuan yang sama juga dilakukan terhadap larutan blanko yang mengandung $25 \mathrm{~mL}$ larutan $\mathrm{NaOH} 1 \mathrm{M}$ yang telah dibakukan. Campuran disaring dan residunya dibilas dengan akuades. Filtrat dan bilasan ditambahkan 2 tetes indikator fenolftalein (PP) kemudian dititrasi dengan larutan standar $\mathrm{HCl} 1 \mathrm{M}$ yang sudah dibakukan.

Keasaman total dapat ditentukan dengan menggunakan rumus:

$$
K_{a l}\left(\frac{\text { mmol }}{g}\right)=\left(\frac{\text { mmol NaOH }_{\text {awal }}-\text { mmol NaOH }_{\text {akhir }}}{\text { berat sampel }}\right)
$$

\subsubsection{Penentuan Luas Permukaan Silika Gel Terimobilisasi EDTA-Ag}

Larutan metilen biru $2 \mathrm{mg} / \mathrm{L}$ diukur absorbansinya pada panjang gelombang 550-700 nm dengan spektrofotometer UV-Vis. Kemudian ditentukan panjang gelombang maksimum dan dibuat kurva standar metilen biru dengan konsentrasi $0 ; 1 \mathrm{mg} / \mathrm{L} ; 1,5 \mathrm{mg} / \mathrm{L} ; 2 \mathrm{mg} / \mathrm{L}$ dan diukur absorbansinya pada panjang gelombang maksimum. Dari data yang diperoleh, dibuat kurva standar metilen biru $(\mathrm{mg} / \mathrm{L}) \cdot 0,1 \mathrm{~g}$ silika gel terimobilisasi EDTA-Ag ditambahkan ke dalam $25 \mathrm{~mL}$ larutan metilen biru $20 \mathrm{mg} / \mathrm{L}$,diaduk dengan waktu kontak 30 menit, 40 menit, 50 menit, 60 menit dan 70 menit, disaring dan diukur absorbansinya pada panjang gelombang maksimum metilen biru.

Luas pemukaan silika gel terimobilisasi EDTA-Ag dihitung menggunakan persamaan:

$$
\mathbf{S}=\frac{\mathbf{X m} \times \mathbf{N} \times \mathbf{A}}{\mathbf{M r}}
$$

Dimana $\mathrm{S}$ adalah luas permukaan $\left(\mathrm{m}^{2} / \mathrm{g}\right), \mathrm{Xm}$ adalah daya serap optimum dari adsorben terhadap metilen biru $(\mathrm{mg} / \mathrm{g}), \mathrm{N}$ adalah bilangan Avogadro $\left(6,02 \times 10^{23} \mathrm{~mol}^{-1}\right), \mathrm{A}$ adalah luas permukaan 1 molekul metilen biru $\left(197 \times 10^{-20} \mathrm{~m}^{2} /\right.$ molekul $)$ dan $\mathrm{Mr}$ adalah masa molekul relatif metilen biru $(319,86 \mathrm{gram} / \mathrm{mol})$. Penentuan nilai Xm dapat dihitung menggunakan persamaan:

$$
\mathbf{X m}=(\mathbf{C o}-\mathbf{C s}) \times \frac{\mathbf{V}}{\mathbf{m}}
$$

Dimana Co adalah konsentrasi metilen biru awal (mg/L), Cs adalah konsentrasi metilen biru akhir (mg/L), $\mathrm{V}$ adalah volume metilen biru yang digunakan (L) dan m adalah berat sampel silika terimobilisasi EDTA-Ag (g). 2.2.6 Pembuatan Plastik Anti bakteri

Kitosan dengan variasi 0,3 dan 0,7 gram masing-masing dilarutkan dalam $50 \mathrm{~mL}$ larutan $\mathrm{CH}_{3} \mathrm{COOH} 1 \%$ (v/v) dan diaduk selama 24 jam, ditambahkan silika gel terimobilisasi EDTA-Ag hasil karakterisasi pada 
prosedur yang memiliki luas permukaan paling besar. Kemudian larutan disaring dan masing-masing rasio kitosan dicetak $50 \mathrm{~mL}$ ke dalam cawan petri (diameter $15 \mathrm{~cm}$ ) dan dikeringkan pada suhu $65^{\circ} \mathrm{C}$ selama $7 \mathrm{jam}$ Kemudian plastik yang terbentuk dilepaskan dari cawan petri dengan menggunakan $\mathrm{NaOH} 3 \mathrm{M}$ dan dicuci secara bertahap sampai netral $(\mathrm{pH}=7)$ dengan menggunakan akuades dan dikeringkan pada suhu kamar.

\subsubsection{Uji Mekanis Sampel Plastik}

Dipotong sampel plastik, kedua ujung sampel dijepit, lalu dicatat panjang awal kemudian ditambahkan beban pada sampel dan dicatat panjang akhir sampel. Pengujian dihitung menggunakan rumus:

$$
\text { Elongasi }(\%)=\frac{1-10}{\text { lo }} \times 100 \%
$$

Dimana 1 adalah panjang akhir dan $1_{0}$ adalah panjang mula-mula.

\section{Hasil dan Pembahasan}

\subsection{Preparasi Abu Sekam Padi}

Sekam padi disangrai untuk menguraikan senyawa-senyawa organik seperti selulosa dan lignin menjadi uap air, karbon dan juga karbon dioksida sehingga menurunkan temperatur dan mempercepat proses pengabuan. Saat sangrai terjadi perubahan warna sekam padi menjadi hitam yang menunjukkan bahwa senyawa-senyawa organik tersebut belum teroksidasi sempurna walau telah terdekomposisi. Sekam padi hasil sangrai ditunjukkan pada Gambar 1.

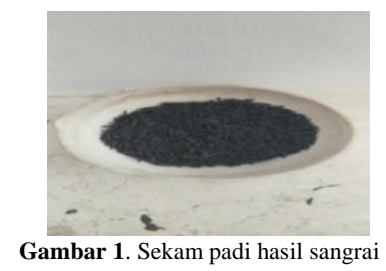

Sisa komponen organik dan proses oksidasi secara sempurna semua karbon menjadi $\mathrm{CO}_{2}$, hidrogen menjadi $\mathrm{H}_{2} \mathrm{O}$ dan silika menjadi $\mathrm{SiO}_{2}$ dilakukan dengan tanur. Pengabuan dilakukan pada suhu $700^{\circ} \mathrm{C}$ untuk menghasilkan silika yang berstruktur amorf. Apabila pengabuan dilakukan pada temperatur di bawah $700^{\circ} \mathrm{C}$ maka kadar silika yang dihasilkan akan lebih rendah, sebaliknya apabila pengabuan dilakukan pada temperatur di atas $700^{\circ} \mathrm{C}$ maka akan menghasilkan silika berstruktur kristal yang bersifat stabil sehingga sangat sukar dilebur dan bereaksi (Nuryono, 2004). Abu hasil pentanuran berwarna putih menunjukkan adanya kandungan silika yang tinggi dan berstruktur amorf (Anggo dkk., 1988 dalam Bolle, 2010). Abu sekam padi hasil pengabuan ditunjukkan pada Gambar 2.

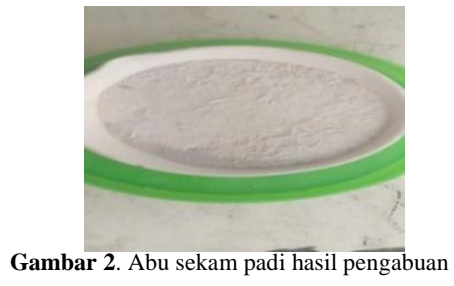

Proses pemurnian silika menggunakan asam klorida ditunjukkan pada Gambar 3. Tujuan pemurnian menggunakan larutan $\mathrm{HCl}$ (kondisi asam) adalah untuk menghilangkan oksida-oksida logam yang merupakan pengotor dalam abu sekam padi seperti $\mathrm{Na}_{2} \mathrm{O}, \mathrm{K}_{2} \mathrm{O}, \mathrm{MgO}, \mathrm{CaO}, \mathrm{P}_{2} \mathrm{O}_{5}$ dan $\mathrm{Fe}_{2} \mathrm{O}_{3}$ (Nenohaifeto dkk., 2016)

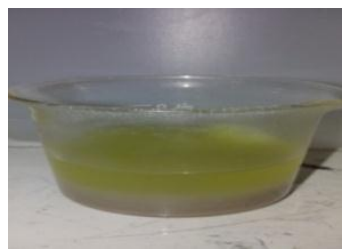

Gambar 3. Pemurnian silika menggunakan $\mathrm{HCl}$

Pembilasan menggunakan akuades sampai $\mathrm{pH}$ netral dilakukan untuk menghilangkan ion $\mathrm{Cl}^{-}$karena ion $\mathrm{H}^{+}$akan membentuk ikatan dengan molekul $\mathrm{H}_{2} \mathrm{O}$ membentuk ion hidronium $\left(\mathrm{H}_{3} \mathrm{O}^{+}\right)$yang akan mengikat ion $\mathrm{Cl}^{-}$tersebut (Wogo dkk., 2013). Rendemen silika dalam abu sekam padi diperoleh sebesar 468,04 gram dengan kadar silika sebesar 93,608\%. Silika hasil pemurnian ditunjukkan pada Gambar 4.

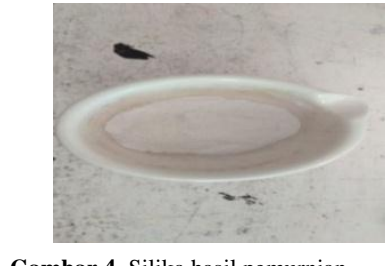

Gambar 4. Silika hasil pemurnian
Alasan dilakukan pendidihan terlebih dahulu dikarenakan silika hanya dapat dilebur dengan memanfaatkan kelarutannya yang sangat besar pada $\mathrm{pH} \geq 10$ sehingga dapat mempermudah proses peleburan (Nuryono, 2004). Hasil peleburan berupa padatan berwarna putih keabuan dengan tekstur beronggarongga seperti pada Gambar 5a. Larutan hasil penyaringan merupakan larutan natrium silikat (Gambar 5b). Indikator awal terbentuknya larutan natrium silika yaitu akan terasa licin jika larutan mengenai permukaan kulit (Ngatidjo dkk., 2011).

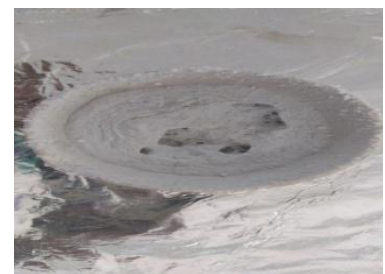

a.

Gambar 5.a. Silika hasil peleburan

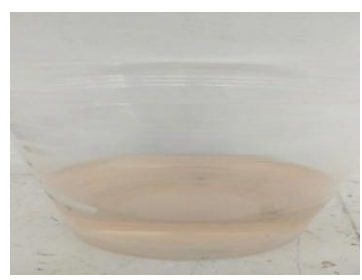

Perkiraan model mekanisme reaksi pembentukan natrium silikat adalah sebagai berikut:

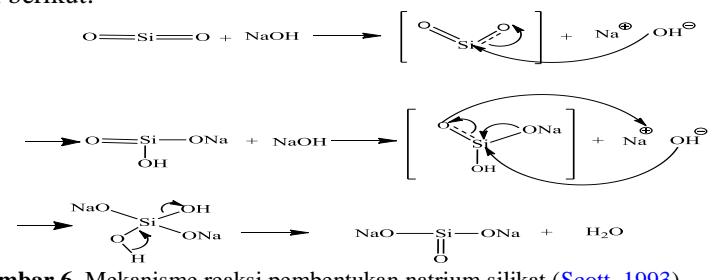

Gambar 6. Mekanisme reaksi pembentukan natrium silikat (Scott, 1993)

\subsection{Pembuatan Silika Gel Terimobilisasi EDTA-Ag}

Tujuan digunakan wadah plastik karena wadah gelas mengandung silika yang kemungkinan akan bereaksi dengan EDTA dan $\mathrm{AgNO}_{3}$ serta akan mempengaruhi hasil yang diperoleh (Adoe dkk., 2016). Proses pembentukan gel ini merupakan proses netralisasi yang menghasilkan silika gel terimobilisas EDTA-Ag melalui penambahan asam klorida (Wogo dkk., 2017). Reaksi pembentukan gel silika dapat dilihat pada Gambar 7:

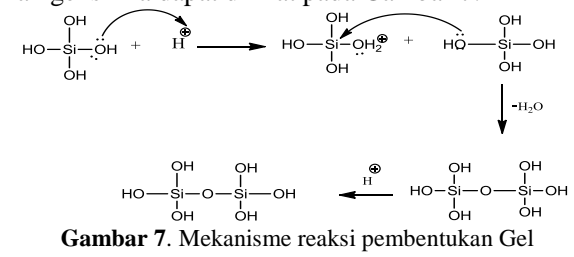

Pada Gambar 7, menurut Adoe dkk (2016) dan Nenohaifeto dkk (2016), larutan asam klorida yang ditambahkan ke dalam campuran larutan natrium silikat, EDTA dan $\mathrm{AgNO}_{3}$ akan meningkatkan konsentrasi proton yang kemudian mengubahnya menjadi gugus silanol ( $\equiv \mathrm{Si}-\mathrm{OH})$. Pada kondisi $\mathrm{pH}$ netral, jumlah gugus silanol $(\equiv \mathrm{Si}-\mathrm{OH})$ dan siloksi terprotonasi $\left(\equiv \mathrm{Si}-\mathrm{O}^{-}+\mathrm{H}^{+}\right)$ seimbang membentuk gugus siloksan $(\equiv \mathrm{Si}-\mathrm{O}-\mathrm{Si} \equiv)$ pada akhir reaksi. Proses pembentukan gel terjadi melalui reaksi pembentukan ikatan siloksan ( $\mathrm{Si}-\mathrm{O}-\mathrm{Si}$ ) dari silikat (Nuryono dan Narsito, 2005). Serbuk silika gel yang dihasilkan terlihat pada Gambar 8 .

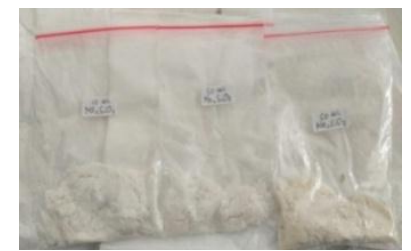

Gambar 8. Serbuk silika gelterimobilisasi EDTA-Ag

Serbuk silika gel dengan volume natrium silikat $10 \mathrm{~mL}$ dan $30 \mathrm{~mL}$ berwarna putih sedangkan sampel dengan volume natrium silikat $50 \mathrm{~mL}$ berwarna sedikit coklat.

Silika gel terimobilisasi EDTA-Ag terbentuk melalui ikatan koordinasi antara logam $\mathrm{Ag}$ dengan atom $\mathrm{O}$ dari gugus $-\mathrm{OH}$ yang bersifat elektronegatif pada permukaan silika gel dan EDTA (Wogo dkk., 2017). Berikut perkiraan mekanisme terikatnya logam Ag pada silika dan EDTA.

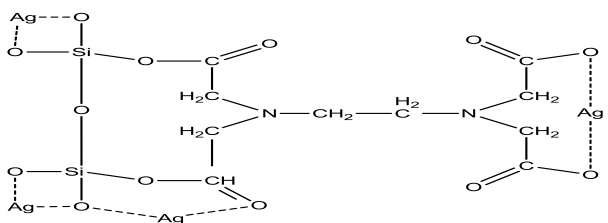

Gambar 9. Perkiraan mekanisme reaksi terikatnya logam Ag pada silika dan EDTA 


\subsection{Penentuan Keasaman Permukaan}

Pada Penentuan keasaman dilakukan dengan menggunakan metode titrasi asam basa. Tujuan penentuan keasaman permukaan yaitu untuk mengetahui jumlah mmol situs asam yang terikat pada tiap gram adsorben. Data keasaman larutan dapat dilihat pada Tabel 1 .

\begin{tabular}{cc} 
Tabel 1. Keasaman Permukaan Silika Gel Terimobilisasi EDTA-Ag \\
\hline $\begin{array}{c}\text { Jenis Gel } \\
\text { Terimobilisasi EDTA- } \\
\text { Ag }\end{array}$ & $\begin{array}{c}\text { Keasaman Permukaan } \\
\mathrm{K}_{\mathrm{A}}(\mathrm{mmol} / \mathrm{g})\end{array}$ \\
\hline $\mathrm{A}$ & 3,4 \\
$\mathrm{~B}$ & 2,6 \\
$\mathrm{C}$ & 2,4 \\
\hline
\end{tabular}

Keterangan: Sampel A adalah silika gel terimobilisasi EDTA-Ag dengan jumlah larutan natrium silikat $10 \mathrm{~mL}$, sampel $\mathrm{B}$ dengan jumlah larutan natrium silikat $30 \mathrm{~mL}$, sampel $\mathrm{C}$ dengan jumlah larutan natrium silikat $50 \mathrm{~mL}$.

Berdasarkan Tabel 1 menunjukkan bahwa semakin sedikit volume $\mathrm{HCl}$ yang dibutuhkan saat titrasi penentuan keasaman permukaan, maka semakin besar situs asam yang terdapat pada permukaan adsorben (Noni, 2015).

\subsection{Penentuan Luas Permukaan Menggunakan Metode Metilen Biru}

Penentuan luas permukaan dilakukan dengn

tujuan untuk mengetahui besarnya kapasitas serapan maksimum (banyaknya zat yang teradsorpsi) dari masing-masing adsorben seiring dengan meningkatnya waktu kontak. Hasil pengukur menunjukkan bahwa panjang maksimum metilen bahwa adalah sebesar $658 \mathrm{~nm}$ dengan absorbansi sebesar 0,401. Kurva standar metilen biru ditunjukkan pada Gambar 10 .

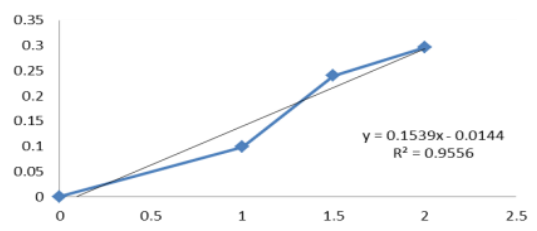

Gambar 10. Grafik kurva standar metilen biru

Data luas permukaan sampel ditunjukkan pada Tabel 2.

\begin{tabular}{cccc}
\multicolumn{4}{c}{ Tabel 2. Data Luas Permukaan } \\
\hline $\begin{array}{c}\text { Waktu } \\
\text { Kontak } \\
(\text { menit })\end{array}$ & \multicolumn{3}{c}{$\begin{array}{c}\text { Luas } \\
\text { PermukaanSampel } \\
\left(\mathrm{m}^{2} / \mathrm{g}\right)\end{array}$} \\
\cline { 2 - 4 } & $\mathrm{A}$ & $\mathrm{B}$ & $\mathrm{C}$ \\
\hline 40 & 17,05375 & 16,78103 & 16,58171 \\
50 & 17,29012 & 17,10222 & 16,99922 \\
60 & 17,52645 & 17,24769 & 17,02949 \\
70 & 17,56279 & 17,54462 & 17,11702 \\
80 & 17,51432 & $\mathbf{1 7 , 6 1 1 3 1}$ & 16,78711 \\
\hline
\end{tabular}

Berdasarkan Tabel 2 dapat dijelaskan bahwa semakin lama waktu kontak maka akan semakin banyak molekul metilen biru yang terserap. Waktu kontak maksimum sampel A dan sampel C adalah 70 menit sedangkan sampel B adalah 80 menit. Hal ini berarti pada sampel A dan B telah melewati titik jenuh sehingga pada waktu kontak 80 menit mengalami penurunan daya serap terhadap larutan metilen biru. Sampel dengan luas permukaan tertinggi adalah sampel dengan volume larutan natrium silikat sebanyak $30 \mathrm{~mL}$

\subsection{Penentuan Gugus Fungsi Menggunakan FTIR}

Penentuan gugus fungsi menggunakan Spektrofotometer Transform Infra Red (FTIR) dilakukan untuk mengetahui bahwa silika gel sudah terimobilisasi EDTA-Ag dengan melihat spektrum yang dihasilkan. Berikut merupakan spektra hasil analisis FTIR (Gambar 11). Sedangkan data hasil analisis FTIR ditunjukkan pada Tabel 3.

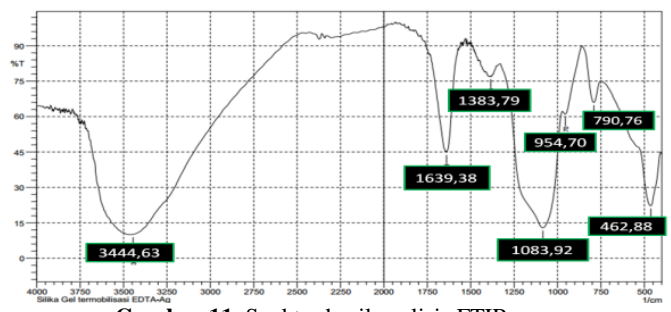

Gambar 11. Spektra hasil analisis FTIR

Tabel 3. Interpretasi Spektra FTIR Sampel Silika Gel Terimobilisasi EDTA-Ag

\begin{tabular}{lc}
\hline \multicolumn{1}{c}{ GugusFungsi } & Frekuensi Daerah Serapan $\left(\mathrm{cm}^{-1}\right)$ \\
\hline Vibrasiulur $-\mathrm{OH}(\equiv \mathrm{Si}-\mathrm{OH})$ & 3444,63 \\
Vibrasiulur $\mathrm{C}=\mathrm{O}(-\mathrm{NHCOCH})$ & 1639,38 \\
Vibrasitekuksimetri $\mathrm{CH}\left(\mathrm{CH}_{2}\right)$ & 1384,79 \\
Vibrasiulurasimetri $\equiv \mathrm{Si}-\mathrm{O}(\equiv \mathrm{Si}-\mathrm{O}-\mathrm{Si} \equiv)$ & 1083,92 \\
Vibrasiulur $\equiv \mathrm{Si}-\mathrm{O}(\equiv \mathrm{Si}-\mathrm{OH})$ & 954,70
\end{tabular}

Vibrasiulursimetris $\equiv \mathrm{Si}-\mathrm{O}(\equiv \mathrm{Si}-\mathrm{O}-\mathrm{Si} \equiv)$ 790,76

Berdasarkan data pada Tabel 3 menunjukkan bahwa sampel benar telah terimobilisasi EDTA-Ag. Hal ini dibuktikan dengan adanya gugus-gugus silanol dan siloksan dari silika gel, gugus $-\mathrm{CH}_{2}$, gugus $-\mathrm{NHCOCH}_{3}$ dari EDTA dan adanya logam Ag dalam silika yang tidak terlihat namun dapat dideteksi melalui tidak adanya serapan gugus $\mathrm{C}-\mathrm{N}$ pada bilangan gelombang $1700 \mathrm{~cm}^{-1}$ (Purnawan dkk., 2012)

\subsection{Pembuatan Plastik Antibakteri}

Pada pembuatan plastik digunakan asam asetat sebagai pelarut karena kitosan bersifat basa dan kebanyakan larut pada asam organik atau mineral encer melalui protonasi gugus amino bebas pada $\mathrm{pH}<6,5$. Asam asetat cair memiliki konstanta dielektrik yang kecil sehingga lebih cenderung membentuk pasangan ion dan lebih sering digunakan dalam membentuk senyawa kompleks dan bersifat protik hidrofilik yaitu senyawa asam yang menukarkan sebuah proton (bersifat asam) dan hidrofilik karena larut dalam air. Tujuan dilakukan pengadukan selama 24 jam agar kitosan dapat larut secara sempurna dalam larutan asam asetat sehingga mudah bereaksi dengan bahan lainnya, sedangkan silika gel terimobilisasi EDTA-Ag yang digunakan adalah pada variasi volume larutan natrium silikat $30 \mathrm{~mL}$ yang memiliki luas permukaan optimum.

Penyaringan dilakukan untuk memisahkan larutan dari endapan sampel yang mungkin tidak larut sempurna. Selanjutnyadilakukan pengeringan agar larutan dapat membentuk plastik. Plastik yang terbentuk seperti pada Gambar 12 (a) dan (b).

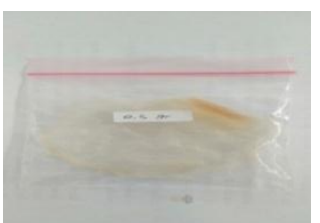

a.

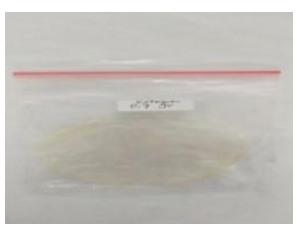

b.
Gambar 12. Plastik dengan variasi kitosan (a) 0,3 gram dan (b) 0,7 gram

\subsection{Uji Mekanis Sampel Plastik}

Tujuan dilakukan uji mekanis yaitu untuk mengetahui tingkat elastisitas sampel yang dinyatakan dalam persen elongasi. Elongasi menunjukkan seberapa besar pertambahan panjang per panjang awal bahan yang diujikan.

Tabel 4. Data Uji Mekanis

\begin{tabular}{cccc}
\hline Jenis Plastik & $\begin{array}{c}\text { Panjang Mula- } \\
\text { mula } \\
\left(l_{o}\right),(\mathrm{cm})\end{array}$ & $\begin{array}{c}\text { Panjang Akhir } \\
(l),(\mathrm{cm})\end{array}$ & $\begin{array}{c}\text { Elongasi } \\
(\%)\end{array}$ \\
\hline $\mathrm{A}$ & 4 & & 27,5 \\
$\mathrm{~B}$ & 4 & 4,1 & 7,5 \\
\hline
\end{tabular}
plastik dengan variasi kitosan 0,7 gram.

Berdasarkan data pada Tabel 4 dapat dijelaskan bahwa persen elongasi sampel dipengaruhi oleh besarnya konsentrasi kitosan. Semakin besar konsentrasi kitosan maka akan semakin rendah persen elongasinya. Sampel A memiliki persen elongasi yang lebih besar. Hal ini disebabkan karena kadar kitosan yang sedikit yaitu 0,3 gram. Sedangkan sampel B memiliki persen elongasi yang lebih rendah. Hal ini disebabkan karena kadar kitosan yang tinggi yaitu 0,7 gram. Semakin besar konsentrasi kitosan maka ikatan hidrogen yang terdapat didalam plastik juga akan semakin kuat, padat dan kaku dikarenakan jarak antar molekul lebih rapat sehingga ikatan kimia dari plastik akan semakin kuat dan sulit untuk diputus, karena memerlukan energi yang besar. Semakin banyak kitosan yang ditambahkan, maka elongasi akan menurun. Penurunan elastisitas ini disebabkan oleh semakin menurunnya jarak ikatan antar molekulnya, karena titik jenuh telah terlampaui sehingga akan menurunkan gaya intermolekul antar rantai, menyebabkan gerakan antar rantai lebih bebas sehingga fleksibilitas mengalami peningkatan atau semakin elastis (Coniwanti dkk., 2014).

\section{Simpulan}

Berdasarkan penelitian yang telah dilakukan dapat diambil kesimpulan, bahwa semakin tinggi volume larutan natrium silikat maka keasaman permukaan silika terimobilisasi EDTA-Ag semakin menurun. Sedangkan luas permukaan optimum yaitu $17,61131 \mathrm{~m}^{2} / \mathrm{g}$ untuk volume silika $30 \mathrm{~mL}$ pada waktu kontak 80 menit.

Kitosan memiliki pengaruh terhadap kelenturan plastik antibakteri dari komposit silika gel terimobilisasi EDTA-Ag dimana semakin besar konsentrasi kitosan maka akan semakin rendah persen elongasinya (7,5-27,5\% untuk variasi kitosan 0,7 dan 0,3 gram).

Pustaka

Adoe, K. A., Wogo, H. E dan Siburian, R. A. F. 2016. Sintesis Silika Gel Terimobilisasi EDTA-Ag sebagai Bahan Antibakteri Escherichia Coli. Prosiding Seminar Nasional 1 Laboratorium Riset Terpadu Undana, hal. 187-196. 
Bolle, T. C. M. 2010. Sintesis Silika Gel Terimobilisasi Dithizon dari Abu Sekam Padi. Skripsi, Jurusan Kimia, FST, Universitas Nusa Cendana, Kupang.

Coniwanti, P., Linda, L., dan Mardiyah, R. A. 2014. Pembuatan Film Plastik Biodegradable dari Pati Jagung dengan Penambahan Kitosan dan Pemlastis Gliserol, Jurnal Teknik Kimia, 20 (4): 22-30.

Da Silva, M. D. 2009. Impregnasi Dithizon pada Silika Gel Hasil Pengolahan Abu Sekam Padi, Skripsi, Jurusan Kimia, FST, Universitas Nusa Cendana, Kupang.

Folleto, E. L., Ederson, G., Leonardo, H. O., Sergio, J. 2006. Conversion of Rice Hull Ash Into Sodium Silicate, Material Research, Vol. 9, No. 3,335338, Brazil.

Fahmiati, Nuryono dan Narsito. 2004. Kajian Kinetika Adsorpsi Cd(II), Ni(II) dan $\mathrm{Mg}(\mathrm{II})$ pada Silika Gel Termodifikasi 3-Merkapto-1,2,4-triazol, Alchemy, 3(2), 22-28.

Hyung, J. J., Sung C. Y., Seong, G. O. 2003. Preparation and Antibacterial Effect of $\mathrm{Ag}-\mathrm{SiO}_{2}$ Thin Films by Sol-Gel Method, Biomaterials, 24, 49214928.

Kalaphaty, U., Proctor, A., Shultz, J. 2002. An Improved Method for Production of Silica from Rice Hull Ash, Bioresource Technology, 85(3): $285-$ 289.

Nenohaifeto, A. N., Wogo, H. E dan Tawa, B. D. 2016. Pmanfaatan Silika Gel Terimobilisasi EDTA-Ag sebagai Bahan Antibakteri Staphylococcus Aureus, Prosiding Seminar Nasional 1 Laboratorium Riset Terpedu Undana, hal. 99-106.

Ngatidjo., Faried, F dan Lestari, I. 2011. Pemanfaatan Abu Sekam Padi (ASP) Payo dari Kerinci Sebagai Sumber Silika dan Aplikasinya Dalam Ekstraksi Fasa Padat Ion Tembaga (II), JurnalPenelitian Universitas Jambi Seri Sains, Vol. 13, No. 2, Hal. 47-52.

Noni, P. 2015. Sintesis Silika Gel Terimobilisasi EDTA sebagai Adsorben Ion $P b(I I)$, Skripsi, Jurusan Kimia, FST, Universitas Nusa Cendana, Kupang.
Nuryono, 2004. Pengaruh Konsentrasi NaOH pada Destruksi Silika Abu Sekam Padi Cara Basah, Prosiding Seminar Nasional MIPA diselenggarakan oleh FMIPA UNDIP, 4 Desember 2004.

Nuryono dan Narsito, 2005. Pengaruh Konsentrasi Asam Terhadap Karakter Silika Gel Hasil Sintesis dari Natrium Silikat, Indo. J. Chem, 5 (1): 23-30.

Oscik, J., 1982. Adsorption, John Wiley and Sons, New York.

Prasetyo, K. W. 2004. Pemanfaatan Limbah Cangkang Udang sebagai Bahan Pengawet Kayu Ramah Lingkungan. S Hut UPT Balitbang Biomaterial LII Cibinong, Bogor.

Purnawan, C., Wibowo, A. H., Samiyatun. 2012. Kajian Ikatan Hidrogen dan Kristalinitas Kitosan Dalam Proses Adsorbsi Ion Logam Perak (Ag). Jurnal, Molekul, Vol. 7, No. 2, 121-129, Universitas Sebelas Maret, Surakarta.

Scott, R. P. W. 1993. Silica Gel and Bonded Phase, Willey and Sons Ltd, Chichester, P. 2-14, 23-25, 43-54.

Tambaru, D., Wogo, H. E., Atitus, E .R., 2010. Sintesis dan Karakterisasi Silika Gel dari Abu Sekam Padi serta Pemanfaatannya pada Penurunan Kesadahan Air, Buletin Penelitian dan Pengembangan (Research and Development) Indonesia AustraliaEastern Universities Project, Vol. 11, No. 2, Hal 99-108.

Wogo, H. E., Nitbani, F. O., dan Tjitda P. J. P., 2013. Sintesis Lempung Terinterkalasi Anilin dan Pemanfaatannya sebagai Adsorben Fenol, Sains dan Terapan Kimia, Vol. 7, No. 1, Jurusan Kimia FST Universitas Nusa Cendana, Kupang.

Wogo, H. E., Kedjo, G. Y., Selan, O. Th. E dan Ola, A. R. B., 2017. Sintesis Plastik Antibakteri, Prosiding Seminar Nasional 2 Laboratorium Riset Terpadu Undana 2017, hal. 15-2. 